\title{
Hearing Disorders in Congenital Toxoplasmosis: A Literature Review
}

\author{
Camila de Castro Corrêa ${ }^{1}$ Luciana Paula Maximino ${ }^{2}$ \\ ${ }^{1}$ Department of Ophthalmology and Otorhinolaryngology, Faculdade \\ de Medicina de Botucatu, Universidade Estadual Paulista (Unesp), \\ Botucatu, Brazil \\ 2 Department of Speech-Language Pathology and Audiology, \\ Faculdade de Odontologia de Bauru (FOB), Universidade de Sãoo \\ Paulo (USP), Bauru, Brazil
}

\author{
Silke Anna Theresa Weber ${ }^{1}$
}

Int Arch Otorhinolaryngol 2018;22:330-333.

\begin{abstract}
Address for correspondence Camila de Castro Corrêa, SL, MS, PhD student, Distrito de Rubião Júnior s/n, Botucatu, SP, 18618-970, Brazil (e-mail: camila.ccorrea@hotmail.com).
\end{abstract}

Abstract
Keywords
- speech, language and
hearing sciences
- toxoplasmosis
- toxoplasmosis,
congenital
- hearing
- hearing disorders

Introduction Several studies show correlations between congenital toxoplasmosis and hearing loss, with a broad diversity of levels of hearing loss and specifications of hearing disorders.

Objective To describe the studies found in the literature regarding hearing disorders in congenital toxoplasmosis.

Data Synthesis A literature review was conducted on the Lilacs, SciELO, PubMed and Scopus databases by combining the following keywords: congenital toxoplasmosis and hearing. Based on this search strategy, 152 papers were found, the majority published on the Scopus and PubMed databases from 1958 to 2015. After the application of the inclusion criteria, 8 articles published between 1980 and 2015 were included in the present study. Conclusion This review showed a moderate evidence of the association between hearing disorders and congenital toxoplasmosis, which is characterized by sensorineural hearing loss. However, there are gaps in the description of the specific characteristics of the type and level of hearing loss, or of other possible disorders involved in the auditory processing.

\section{Introduction}

Toxoplasmosis is a systemic infection caused by the protozoan parasite Toxoplasma gondii, which is transmitted through the ingestion of contaminated food. Less frequently, toxoplasmosis is acquired by blood transfusion or an organ transplant. Congenital toxoplasmosis, which is caused by vertical transmission from the mother to the fetus, has an estimated prevalence of $20 \%$ of infected mothers transmitting the parasite to the fetus. ${ }^{1}$ It is worth mentioning that this prevalence varies according to the period of pregnancy during which the mother acquired the infection, the geographical location, and if the mother underwent prenatal monitoring. ${ }^{2}$

Vertical transmission can be detected early in pregnancy, and must be treated with oral spiramycin to prevent transmission to the fetus through the placenta. But if the infection occurs in the fetus, the treatment must include pyrimethamine, sulfadiazine and folinic acid. ${ }^{3}$

The classic symptoms of congenital toxoplasmosis are intracranial calcifications, chorioretinitis and hydrocephalus. The diagnosis of congenital toxoplasmosis is made by serologic testing.

Several studies suggest a correlation between hearing disorders and congenital toxoplasmosis, which would be triggered by the neurological involvement. However, there are no specifications of the type and level of hearing loss, or other possible disorders involved in the auditory processing. 4,5

The articles report congenital toxoplasmosis as being a risk factor for hearing loss, ${ }^{6,7}$ and they also point out the doubts about the exact explanation of the origin of the hearing loss in congenital toxoplasmosis, ${ }^{8}$ as well as the uncertainty of the received

March 13, 2017

accepted

July 5, 2017

published online

August 7, 2017
DOI https://doi.org/

10.1055/s-0037-1605377. ISSN 1809-9777.
Copyright (e 2018 by Thieme Revinter

Publicações Ltda, Rio de Janeiro, Brazil
License terms

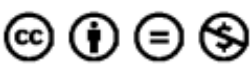


correlation. ${ }^{9}$ Salviz et al pointed out that the possible pathophysiology of the hearing loss in congenital toxoplasmosis is due the postnatal inflammatory response against the parasites found in the internal auditory canal and in the temporal bone, specifically in the internal auditory canal, the spiral ligament, the stria vascularis, and the saccular macula. ${ }^{10}$

Thus, the aim of this study was to analyze the actual data of the literature related to hearing disorders in congenital toxoplasmosis.

\section{Review of the Literature}

The literature review was performed on the Lilacs, SciELO, PubMed, and Scopus databases combining the following Health Sciences Descriptors (DeCS, in the Portuguese acronym)/ Medical Subject Headings (MeSH): congenital toxoplasmosis and hearing. The respective terms in Portuguese were also used for the Lilacs and SciELO databases.

The research was performed without time limitation and using the virtual private network (VPN) of one of our universities in order for us to be able to access more articles in their full format. The inclusion criteria were: studies (any type of article, excluding review articles) specifically concerning hearing disorders in congenital toxoplasmosis published in Portuguese, English or Spanish. The authors excluded all articles concerning others aspects of congenital toxoplasmosis, those articles for which the full text was not available, and review articles.

The analysis of the articles was performed in two steps: at first, the articles were selected by their titles and abstracts. When they contemplated the inclusion criteria, they were read in full. The included articles were analyzed for their year of publication, study design, objectives, methods, results and conclusions.

Based on the search strategy, 152 papers were found (3 from Lilacs, 1 from SciELO, 45 from PubMed, and 103 from Scopus); most of them were published on the Scopus and PubMed databases from 1958 to 2015 (-Fig. 1).

Eight articles met the inclusion criteria: 3 articles from the US, 3 from Brazil, 1 from Iran, and 1 from Norway. They were published between 1980 and 2015, and their distribution is shown in - Fig. 2.

As for the design, which relates to the level of evidence, the selected articles were 5 cross-sectional studies (which presented the highest level of evidence among the articles included), 2 cohort studies and 1 case-control study.

The data extracted from each article regarding the year of publication, filiation, study design, casuistry, methods and results are presented in -Table $\mathbf{1}$.

\section{Discussion}

In the literature, there is moderate evidence of the correlation between hearing disorders and congenital toxoplasmosis, but this topic needs more investigation in order to clarify this relationship and to better guide the population about the risks.

In our search strategy, we had no time limitations; however, the selected articles were published from 1980 to 2015, and they are a few studies with high levels of evidence. The studies

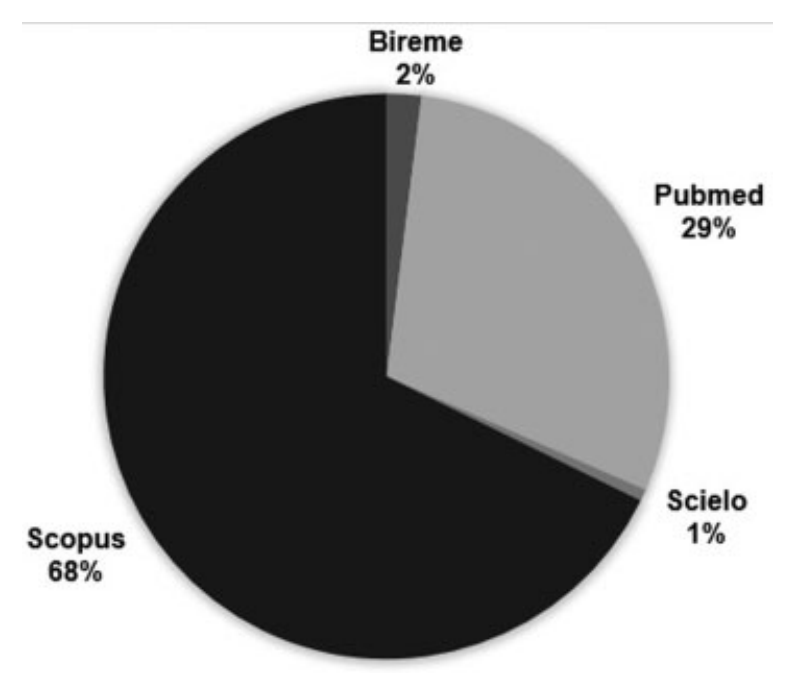

Fig. 1 Distribution of the results of the search strategy using the keywords congenital toxoplasmosis and hearing according to the four databases.

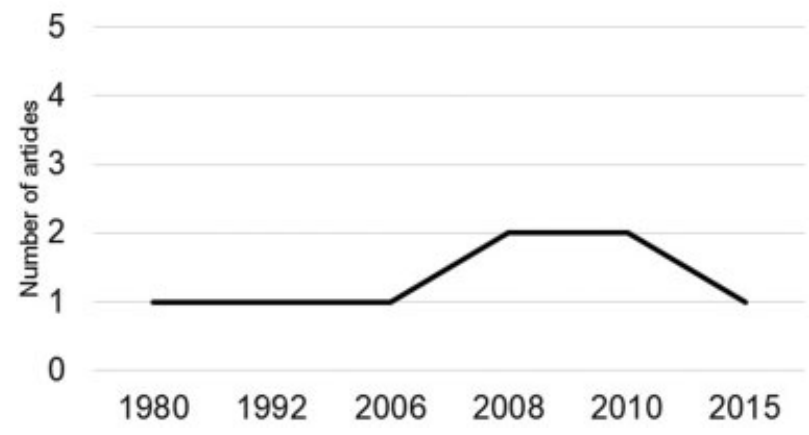

Fig. 2 Distribution of the number of included articles by their year of publication.

were conducted in different countries, and they were based on different treatment times, evaluation and follow-up protocols, which makes it difficult to draw a comparison of the data and perform a meta-analysis.

When analyzing the cross-sectional studies, the incidence of hearing disorders varied greatly, with rates of $3.8 \%, 21.1 \%$, $22 \%$ and $30 \%$ of sensorineural hearing loss, ${ }^{11-13}$ and of $10.55 \%, 12.3 \%$ and $20 \%$ of conductive hearing loss. ${ }^{12-14}$

Other studies, which were based on different methodological designs, showed inconsistency in the incidence of sensorineural hearing loss; one study did not find sensorineural hearing loss in children with congenital toxoplasmosis, ${ }^{15}$ whereas others did. ${ }^{16-18}$

As for the audiological findings, we should consider the different evaluation protocols used in the included studies; some studies used only one test, and others used up to six tests to perform the hearing evaluation. Besides that, the studies considered different patient populations and different moments of evaluation (one evaluation, after the toxoplasmosis treatment and major follow-up evaluation). These characteristics made it impossible to compare the audiological results of the selected studies.

Analyzing all data, we conclude that there is moderate evidence of possible risks of hearing disorders in cases of 
332 Hearing Disorders in Congenital Toxoplasmosis Corrêa et al.

Table 1 Data of the included studies regarding author, year of publication, filiation, study design, casuistry, methods and results

\begin{tabular}{|c|c|c|c|c|c|}
\hline Author, year & $\begin{array}{l}\text { Filiation of main } \\
\text { author, country }\end{array}$ & $\begin{array}{l}\text { Study } \\
\text { design }\end{array}$ & Casuistry & $\begin{array}{l}\text { Methods of performing the } \\
\text { hearing evaluation }\end{array}$ & Results on hearing disorders \\
\hline $\begin{array}{l}\text { Wilson } \\
\text { et al, } 1980^{11}\end{array}$ & $\begin{array}{l}\text { Stanford University } \\
\text { School of Medicine, US }\end{array}$ & CSS & $\begin{array}{l}24 \text { children (follow-up) with } \\
\text { congenital toxoplasmosis }\end{array}$ & $\begin{array}{l}\text { Pure-tone and speech recep- } \\
\text { tion threshold audiometry. }\end{array}$ & $\begin{array}{l}\text { The incidence of SNHL ranged from } \\
22 \text { to } 30 \% \text {. }\end{array}$ \\
\hline $\begin{array}{l}\text { McGee } \\
\text { et al, } 1992^{14}\end{array}$ & $\begin{array}{l}\text { University of } \\
\text { Chicago, US }\end{array}$ & CSS & $\begin{array}{l}30 \text { infants within } 2 \text { months of } \\
\text { birth }\end{array}$ & $A B R$. & $\begin{array}{l}\text { A total of } 6(20 \%) \text { of the } 30 \text { infants } \\
\text { were diagnosed with mild to } \\
\text { moderate conductive hearing loss } \\
\text { associated with otitis media. } \\
\text { Sensorineural hearing loss was not } \\
\text { described. }\end{array}$ \\
\hline $\begin{array}{l}\text { McLeod } \\
\text { et al, } 2006^{15}\end{array}$ & $\begin{array}{l}\text { University of } \\
\text { Chicago, US }\end{array}$ & CS & $\begin{array}{l}131 \text { infants (follow-up) with } \\
\text { congenital toxoplasmosis }\end{array}$ & Not described. & None had SNHL. \\
\hline $\begin{array}{l}\text { Andrade } \\
\text { et al, } 2008^{12}\end{array}$ & $\begin{array}{l}\text { University of Minas } \\
\text { Gerais, Brazil }\end{array}$ & CSS & $\begin{array}{l}30,808 \text { newborns. Among } \\
\text { them, } 19 \text { newborns } \\
\text { diagnosed with congenital } \\
\text { toxoplasmosis }\end{array}$ & $\begin{array}{l}\text { Hearing test battery: } \\
\text { behavioral observation } \\
\text { audiometry, audiometric, } \\
\text { transient and distortion } \\
\text { product otoacoustic } \\
\text { emission, ABR and } \\
\text { tympanometry. }\end{array}$ & $\begin{array}{l}\text { Out of the children with congenital } \\
\text { toxoplasmosis, } 4 \text { were diagnosed } \\
\text { with SNHL and } 2 \text { with conductive loss. } \\
\text { Considering the SNHL, } 2 \text { children had } \\
\text { mild, } 1 \text { had moderate. and } 1 \text { had } \\
\text { profound hearing loss. Two properly- } \\
\text { treated children persisted with } \\
\text { hearing loss. }\end{array}$ \\
\hline $\begin{array}{l}\text { Noorbakhsh } \\
\text { et al } 2008^{16}\end{array}$ & $\begin{array}{l}\text { University of Medical } \\
\text { Sciences, Iran }\end{array}$ & CCS & $\begin{array}{l}95 \text { infants with SNHL and } \\
63 \text { healthy infants were } \\
\text { compared }\end{array}$ & $\begin{array}{l}\text { Audiologic screening with } \\
\text { ABR, EOAE, and PTA }\end{array}$ & $\begin{array}{l}\text { Antibodies were found in } 12 \% \text { SNHL } \\
\text { children (children aged } 3-5 \text { years } \\
\text { old) and in } 21.2 \% \text { (children younger } \\
\text { than } 1 \text {-year-old), whereas in healthy } \\
\text { children }\end{array}$ \\
\hline $\begin{array}{l}\text { Austeng } \\
\text { et al, } 2010^{17}\end{array}$ & $\begin{array}{l}\text { Fredrikstad Hospital } \\
\text { Trust, Norway }\end{array}$ & CSS & $\begin{array}{l}27,727 \text { children born in } \\
\text { Norway between } 1992-1994\end{array}$ & $\begin{array}{l}\text { Otoscopy, immittance audio- } \\
\text { metry, otoacoustic emissions } \\
\text { and play audiometry, } \\
\text { behavioral audiometry in free } \\
\text { field, or ABR. }\end{array}$ & $\begin{array}{l}40 \text { women had primary Toxoplasma } \\
\text { gondii infection in pregnancy and } \\
\text { none of their neonates had hearing } \\
\text { loss; } 22 \text { children were diagnosed } \\
\text { with hearing loss of other origins. }\end{array}$ \\
\hline $\begin{array}{l}\text { Resende } \\
\text { et al, } 2010^{13}\end{array}$ & $\begin{array}{l}\text { University of Minas } \\
\text { Gerais, Brazil }\end{array}$ & CSS & $\begin{array}{l}106 \text { children diagnosed with } \\
\text { congenital toxoplasmosis in } \\
\text { the neonatal screening } \\
\text { program during } 6 \text { months }\end{array}$ & $\begin{array}{l}\text { Hearing test battery: } \\
\text { behavioral observation } \\
\text { audiometry, ABR, transient } \\
\text { and distortion product } \\
\text { otoacoustic emission, and } \\
\text { tympanometry. }\end{array}$ & $\begin{array}{l}\text { They found normal hearing in } 60 \\
\text { children }(56.6 \%) \text {, conductive } \\
\text { hearing loss in } 13(12.3 \%) \text {, SNHL in } 4 \\
\text { ( } 3.8 \%) \text {, and central hearing } \\
\text { disorders in } 29(27.4 \%) \text {. There was } \\
\text { no difference between children } \\
\text { with additional risks for hearing loss } \\
\text { and children who only had only } \\
\text { toxoplasmosis. }\end{array}$ \\
\hline $\begin{array}{l}\text { Silva } \\
\text { et al, } 2015^{18}\end{array}$ & $\begin{array}{l}\text { São Paulo State } \\
\text { University, Brazil }\end{array}$ & CS & 565 newborns & Transient EOAE & $\begin{array}{l}65(11 \%) \text { newborns had risk factors } \\
\text { for hearing disorders, and } \\
\text { congenital toxoplasmosis was } \\
\text { found in } 1 \text { newborn; } 13 \text { infants } \\
\text { presented hearing loss at retest. }\end{array}$ \\
\hline
\end{tabular}

Abbreviations: ABR, auditory brain stem response; CCS, case-control study; CS, cohort study; CSS, cross-sectional study; EOAE, evoked otoacoustic emissions; PTA, pure tone average; SNHL, sensorineural hearing loss.

congenital toxoplasmosis. Thus, prevention, early diagnosis and treatment of congenital toxoplasmosis in pregnant women are recommended in order to minimize the risk of hearing loss in children. ${ }^{13,16}$

Furthermore, we suggest that new studies should be conducted to improve the specifications about hearing disorders and to standardize the assessments and follow-up protocols for these children.

\section{Final Comments}

This review shows a moderate level of evidence of the association between hearing disorders and congenital toxoplasmosis. However, the specifications of the hearing disorders are still unclear, and the assessment and follow-up protocols have not yet been validated.
Therefore, future studies to determine the impact and origin of the hearing loss in this congenital infection, and its repercussions, for example in language development, are needed.

\section{Compliance with Ethical Standards}

Funding: This study was not funded.

Ethical approval: This article does not contain any studies with human participants performed by any of the authors. Informed consent: there was no need to obtain it.

\section{References}

1 Li XL, Wei HX, Zhang H, Peng HJ, Lindsay DS. A meta analysis on risks of adverse pregnancy outcomes in Toxoplasma gondii infection. PLoS One 2014;9(05):e97775 
2 Torgerson PR, Mastroiacovo P. The global burden of congenital toxoplasmosis: a systematic review. Bull World Health Organ 2013;91(07):501-508

3 Robert Koch Institute. Guideline toxoplasmosis. Epidemiol Bull 2007;42:390-394

4 Chuang Y-C, Chen JY, Ji DD, Su PH. Congenital toxoplasmosis in a neonate with significant neurologic manifestations. J Formos Med Assoc 2012;111(04):232-233

5 Brown ED, Chau JK, Atashband S, Westerberg BD, Kozak FK. A systematic review of neonatal toxoplasmosis exposure and sensorineural hearing loss. Int J Pediatr Otorhinolaryngol 2009; 73(05):707-711

6 Kenna MA. Acquired Hearing Loss in Children. Otolaryngol Clin North Am 2015;48(06):933-953

7 Vos B, Senterre C, Lagasse R, Levêque A; SurdiScreen Group. Newborn hearing screening programme in Belgium: a consensus recommendation on risk factors. BMC Pediatr 2015;15:160

8 Kaye A. Toxoplasmosis: diagnosis, treatment, and prevention in congenitally exposed infants. J Pediatr Health Care 2011;25(06): 355-364

9 Dubey JP, Lago EG, Gennari SM, Su C, Jones JL. Toxoplasmosis in humans and animals in Brazil: high prevalence, high burden of disease, and epidemiology. Parasitology 2012;139(11):1375-1424

10 Salviz M, Montoya JG, Nadol JB, Santos F. Otopathology in congenital toxoplasmosis. Otol Neurotol 2013;34(06):1165-1169

11 Wilson CB, Remington JS, Stagno S, Reynolds DW. Development of adverse sequelae in children born with subclinical congenital Toxoplasma infection. Pediatrics 1980;66(05):767-774
12 Andrade GM, Resende LM, Goulart EMA, Siqueira AL, Vitor RWA, Januario JN. Hearing loss in congenital toxoplasmosis detected by newborn screening. Rev Bras Otorrinolaringol (Engl Ed) 2008; 74(01):21-28

13 Resende LM, Andrade GMQ Azevedo MF, Perissinoto J, Vieira ABC. Congenital toxoplasmosis: Auditory and language outcomes in early diagnosed and treated children. Sci Med (Porto Alegre) 2010;20(01):13-19

14 McGee T, Wolters C, Stein L, et al. Absence of sensorineural hearing loss in treated infants and children with congenital toxoplasmosis. Otolaryngol Head Neck Surg 1992;106(01): $75-80$

15 McLeod R, Boyer K, Karrison T, et al; Toxoplasmosis Study Group. Outcome of treatment for congenital toxoplasmosis, 1981-2004: the National Collaborative Chicago-Based, Congenital Toxoplasmosis Study. Clin Infect Dis 2006;42(10): 1383-1394

16 Noorbakhsh S, Memari F, Farhadi M, Tabatabaei A. Sensorineural hearing loss due to Toxoplasma gondii in children: a case-control study. Clin Otolaryngol 2008;33(03):269-273

17 Austeng ME, Eskild A, Jacobsen M, Jenum PA, Whitelaw A, Engdahl B. Maternal infection with toxoplasma gondii in pregnancy and the risk of hearing loss in the offspring. Int J Audiol 2010;49(01): 65-68

18 Silva DP, Lopez PS, Ribeiro GE, Luna MO, Lyra JC, Montovani JC. The importance of retesting the hearing screening as an indicator of the real early hearing disorder. Rev Bras Otorrinolaringol (Engl Ed) 2015;81(04):363-367 